\title{
Comparing Preterm and Term Newborns Serum Adiponectin and Leptin Concentrations and their Correlations with Anthropometric Parameters
}

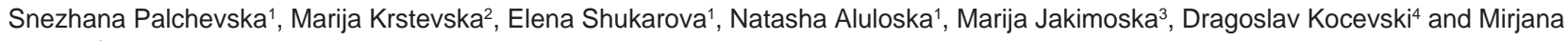
Kocova $^{1}$

${ }^{1}$ Department of Neonatology, Department of Endocrinology and Genetics, Pediatric Clinic, Medical Faculty, University "Ss Cyril and Methodius", Skopje, Republic of Macedonia; '2Department of Medical and Experimental Biochemistry, University "Ss Cyril and Methodius", Medical School, Skopje, Republic of Macedonia; 'Neonatal Unit, Gynecology Clinic, Medical Faculty, University "Ss Cyril and Methodius", Skopje, Republic of Macedonia; "Faculty for Agricultural Science and Food, University "Ss Cyril and Methodius", Skopje, Republic of Macedonia

\begin{abstract}
Citation: Palchevska S, Krstevska M, Shukarova E, Aluloska N, Jakimoska M, Kocevski D, Kocova M. Comparing Preterm and Term Newborns Serum Adiponectin and Leptin Concentrations and their Correlations with Anthropometric and their Correlations with Anthropometric Parameters. Maced J Med Sci. 2012 Oct 15 5(3):317-323. http://dx.doi.org/10.3889/ MJMS.1857-5773.2012.0264.

Key words: leptin; adiponektin; anthropometric parameters; preterm; term newborn.

Correspondence: Dr. Palchevska Snezhana. Pediatric Clinic, Medical Faculty, University "Ss Cyril and Methodius", Skopje, Republic of Macedonia. E-mail: zanpal@hotmail.com

Received: 26-May-2012; Revised: 07-Sep-2012 Accepted: 27-Sep-2012; Online first: 02-Oct-2012

Copyright: () 2012 Palchevska S. This is an open-access article distributed under the terms of the Creative Commons Attribution License, which permits unrestricted use, distribution, and permits unresticted use, distibution, and reproduction in any medium, provided the orig author and source are credited.

Competing Interests: The author have declared that no competing interests exist.
\end{abstract}

\section{Abstract}

Introduction: Serum adipocytokines concentration, their mutual relationship and correlations with anthropometric data could be indicators of fetal and neonatal growth maturity level in term and preterm infants.

Objectives: Study was designed to assess the correlation of the anthropometric parameters with leptin and adiponectin levels in healthy preterm and term newborns.

Design and Methods: $A$ cohort of 110 neonates of both sexes, born pre term (PT) $(n=36)$ or at term (AT) $(n=74)$, additionally classified as AT-AGA $(n=36)$, AT-SGA $(n=18)$, AT-LGA $(n=20)$ and PT-AGA $(n=24)$, PT-SGA ( $n=12)$, according to the Lubchenco curves Mother Body Mass Index-MBMI, Birth Weight-BW, Birth Length-BL, Body Weight/Body Length ratio-BW/BL, Body Mass Index-BMI, Ponderal Index-PI, was recorded after birth.

Results: Sex has no influence on mean serum leptin and adiponectin level. However, differences between AT and PT groups were highly $(p<0.01)$ significant $(2.20 \pm 1.02 ; 30.77 \pm 22.64$ and $1.24 \pm 0.35$; $9.44 \pm 4.82 \mathrm{ng} / \mathrm{mL}$, respectively). Significant difference was found in adiponectin levels between ATAGA and AT-LGA compared to AT-SGA subgroup $(32.8 \pm 25.41$ and $43.40 \pm 16.98 \mathrm{vs} 12.67 \pm 2.45 \mathrm{ng} /$ $\mathrm{mL}$, respectively, $(p<0.01 ; p<0.01)$. There was a significant difference between leptin levels $(1.93 \pm 0.70$; $1.71 \pm 0.53 \mathrm{vs} 3.12 \pm 1.27 \mathrm{ng} / \mathrm{mL}$ ) in AT-AGA and AT-SGA compared to AT-LGA newborns, respectively, $(p<0.01 ; p<0.01)$. No significant differences were found in leptin and adiponectin levels neather between PT subgroups $(1.30 \pm 0.38 \mathrm{ng} / \mathrm{mL})$ nor between PT group and AT-SGA $(1.71 \pm 0.53 \mathrm{ng} / \mathrm{mL})$ subgroup. Leptin and adiponectin levels were positively correlated with all anthropometric parameters: BW, BL, BW/BL, BMI, and PI $(p<0.05)$.

Conclusion: These results indicate that the stage of body growth maturity is positively correlated to adipocytokines involved in fetal growth regulation.

\section{Introduction}

Fetal and infant nutrition and growth have previously been correlated to disease in adulthood [1] Premature infants no matter if they were born small or appropriate for gestational age demonstrate higher prevalence of insulin resistance [2].

Adipokines, predominantly leptin and adiponectin are hormones produced by the adipose 
tissue. Fetal adipokines maturation takes place predominantly in second trimester of pregnancy, playing a role in lipid and glucose metabolism. Since leptin is secreted by adypocites in late stages of differentiation and adiponectin only by fully differentiated adipose cells, they can be used as a marker for adipose tissue development and the amount of adipose tissue. Prenatal growth and gestational age play crucial role in adipose tissue maturation and accumulation, modifying leptin and adiponectin secretion, endocrine secretion and metabolic functions. The inadequately developed fat tissue in premature infants and infants with intrauterine growth restriction lead to impaired glucose metabolism and insulin resistance [3].

Recent studies refer development of obesity, insulin resistance and other metabolic disturbances later in life in patients born preterm or small for gestational age [4]. Leptin is an adipostatic hormone with an important role in feeding behavior, appetite, thermoregulation, body lipid metabolism regulation and energy balance carried out trough multiple hypothalamic pathways $[5,6]$. Leptin acts as a peripheral mediator relaying crucial information regarding body fat status to the brain in children and adults [7]. During pregnancy leptin increases and returns to normal after delivery. Umbilical cord blood concentrations of leptin correlate to baby's birth weight, with higher serum leptin concentrations seen in macrosomic newborns [8].

Studies in term infants indicate significant association of leptin with body mass index, birth weight and insulin with insulin-glucose ratio, leading to conclusion that adipoinsular pathway is already active during fetal and neonatal period. [9, 10]. The metabolic and hormonal changes regarding leptin levels in preterm infants and early postnatal life changes are not well elucidated. Studies have revealed changes in both brain structure and function or illness later in life related to early perinatal events [11-13].

Adiponectin is the most abundant circulating protein derived from the adipose tissue. Its crucial role is protection against insulin resistance development and development of syndrome X [14]. Adiponectin plays an important role in carbonhydrate metabolism favoring peripheral insulin-induced glucose uptake, although evidence of this in the fetal period is lacking [15]. Studies refer inverse relation between serum adiponectin concentrations and serum leptin levels as well as obesity [16]. These observations apply to older children at the age 5-10 years [17].
Contrary to these observations, studies on newborn infants refer serum adiponectin levels positively correlating to birth weight and leptin levels. Studies on adiponectin role in fetal growth revealing it's role in fetal growth are controversial $[18,19]$. Only few studies have been published regarding preterm infants and correlation of circulating adiponectin levels and birth weight, weight gain and serum leptin or insulin levels. Adiponectin levels are referred to be lower in preterm infants at discharge compared to full term, probably due to decreased adiposity. Adiponectin levels were referred to be influenced by being born SGA, weight gain and probably due to dietary long chain polyunsaturated fatty acids (LCPUFAs) [20].

The study was designed to evaluate and compare leptin and adiponectin levels in preterm and term delivered neonatal population and to determine its association with anthropometrics parameters of newborns.

\section{Materials and Methods}

A cohort of 110 (54 female and 56 male) neonates, born from uncomplicated, pregnancies at term $(n=74)$ or preterm $(n=36)$ i.e., between 30 and 42 gestational weeks has been evaluated in the study. Neonates with risk factors (maternal diabetes, stressful delivery, infection, etc.), were excluded from the study.

Anthropometric measurements were made at birth, including length, weight, head circumference, and body weight/body length ratio. Because a single standard anthropometrics factors (BW; BL) cannot assess the nutritional status of newborn properly, we also used combinations of two anthropometric factors: Ponderal index (PI), and Body Mass Index (BMI). PI and BMI are expressed by the following formulas: $\mathrm{PI}=$ body weight $(\mathrm{g})$ / [body length $(\mathrm{cm})]^{3} \times 100$ and $\mathrm{BMI}=$ body weight $(\mathrm{kg}) /$ birth length ${ }^{2}(\mathrm{~m})$.

Neonates were categorized in two groups according the delivery term (AT-delivery at term and PTpreterm delivery) and additionally in subgroups according to the Lubchenco's curves as: Apropriate for gestational age (AGA-birth weight between $10^{\text {th }}$ and $90^{\text {th }}$ percentiles), Large for gestational age (LGA-birth weight above $90^{\text {th }}$ percentile) and Small for gestational age (SGA-birth weight below the $10^{\text {th }}$ percentile) defining AT-AGA, ATSGA, AT-LGA, PT-AGA and PT-SGA subgroups. Gestational age at birth was calculated from the last menstrual period, supported by ultrasound 
Palchevska et al. Preterm and Term Newborns Serum Adiponectin and Leptin Concentrations

measurements and confirmed by Dubowitz scoring.

Serum levels of leptin and adiponectin in fasting state were determined from a blood samples at regular control visit from each neonate. Blood samples were taken at least 48 and before 72 hours after delivery ( third day after delivery) with the purpose of avoiding any bias of hormones deriving from maternal tissues. The blood samples were immediately centrifuged and stored at $20^{\circ} \mathrm{C}$ until assayed.

Serum adiponectin and leptin concentrations were measured by the ELISA method (Human DRG Instruments $\mathrm{GmbH}$, Germany). The limit of sensitivity of the adiponectin assay was $0.78 \mathrm{ng} / \mathrm{ml}$. and the intra- and inter -assay coefficient of variations (CV\%) were 0.9-7.4 and 2.4-8.4 ng/mL respectively. The sensitivity of the DRG Leptin ELISA was $1.0 \mathrm{ng} / \mathrm{mL}$, and the intra- and inter assay CV\% ranged from 5.9 5-6.91 and 8.66-11.55 respectively.

Between group comparison and correlation of the anthropometric parameters with adiponectin and leptin were statistically analyzed using STATISTICA program, one way ANOVA and LSD test, because the data distribution was close to normal. Multiply regression analyses were performed to evaluate Birth Weight and Gestational Age influence on leptin and adiponectin levels.

The study was reviewed and approved by Institutional Rewiev Board of the hospital. Informed consent was obtained from all mothers before the blood samples were taken and inclusion their infants in the study.

\section{Results}

The structure of the studied population infant's anthropometric data, leptin and adiponectin serum concentrations expressed as a mean values of different groups are presented in Table 1, and 2.

Mean birth weight of the newborns classified as AT ( $n=74)$ was $3503.51 \pm 801$ gr and was significantly higher than the birth weight of the PT $(n=36)$ group (1769.17 $\pm 390 \mathrm{gr})$.

Mean birth length, and birth weight/birth length ratio were $50.31 \pm 3.35 \mathrm{~cm},(69.30 \pm 13.99 \mathrm{gr} / \mathrm{cm})$ for $A T$, $42.81 \pm 2.97 \mathrm{~cm},(41.01 \pm 6.79 \mathrm{gr} / \mathrm{cm})$ for PT, respectively. Marked differences between AT and PT group for the birth length and birth weight/birth length ratio were
Table 1: Group distribution, clinical characteristics, leptin and adiponectin concentration in AT and PT newborn's serum of the studied population.

\begin{tabular}{|c|c|c|c|}
\hline & Gestational Age & SGA Prevalence & Gender Female/Male \\
\hline $\begin{array}{l}\text { Studied cohort } \\
(n=110) \\
\text { Preterm newborns (PT) }\end{array}$ & $37.52 \pm 3.36$ & $n=30(27.27 \%)$ & $54 / 56$ \\
\hline$(n=36)$ & $33.13 \pm 1.59$ & $n=12(33.33 \%)$ & $17 / 19$ \\
\hline \multirow[t]{2}{*}{ Term newborns (AT) $(n=74)$} & $39.66 \pm 1.21$ & $n=18(24.32 \%)$ & $37 / 37$ \\
\hline & Term (AT) & Preterm (PT) & All \\
\hline Birth Weight (g) & $3503.51 \pm 801$ & $1769.17 \pm 390$ & $2935.91 \pm 1071$ \\
\hline Birth Length $(\mathrm{cm})$ & $50.31 \pm 3.35$ & $42.81 \pm 2.97$ & $47.85 \pm 4.78$ \\
\hline Birth Weight/Birth Length & & & \\
\hline ratio $(\mathrm{gr} / \mathrm{cm})$ & $69.30 \pm 13.99$ & $41.01 \pm 6.79$ & $60.04 \pm 17.99$ \\
\hline Ponderal (rohrer) index & $3.76 \pm 0.73$ & $2.23 \pm 0.26$ & $2.58 \pm 0.66$ \\
\hline Body Mass Index $\left(\mathrm{kg} / \mathrm{m}^{2}\right)$ & $13.78 \pm 2.89$ & $9.55 \pm 1.20$ & $12.39 \pm 3.17$ \\
\hline \multirow{2}{*}{$\begin{array}{l}\text { Leptin concentration } \\
\text { ( } \mathrm{ng} / \mathrm{mL}) \\
\text { Adiponectin concentration } \\
\text { (ng/mL) }\end{array}$} & $2.20 \pm 1.02^{a}$ & $1.24 \pm 0.35^{\mathrm{a}}$ & $1.88 \pm 0.97$ \\
\hline & $30.77 \pm 22.64^{b}$ & $9.44 \pm 4.82^{b}$ & $23.79 \pm 21.25$ \\
\hline
\end{tabular}

$a, b$ Values with same superscript are significantly different $(p<0.05)$.

noticed for the ponderal and body mass index values, stressing the difference between AT $(3.76 \pm 0.73 ; 13.78$ $\pm 2.89)$ compared to PT $(2.23 \pm 0.26 ; 9.55 \pm 1.20)$, respectively. No marked differences were observed in anthropometric data between sexes within the AT and PT groups.

Sex has no influence on mean serum leptin and adiponectin group or subgroup levels, but almost double and triple differences between AT and PT group were highly $(p<0.01)$ significant $(2.20 \pm 1.02 ; 30.77 \pm 22.64$ and $1.24 \pm 0.35 ; 9.44 \pm 4.82 \mathrm{ng} / \mathrm{mL}$, respectively).

In the AT group significant difference was found in adiponectin levels between AT-AGA and AT-LGA compared to AT-SGA subgroup newborns (32.8 \pm 25.41 and $43.40 \pm 16.98$ vs $12.67 \pm 2.45 \mathrm{ng} / \mathrm{mL}$, respectively,

Table 2: Clinical characteristics of newborns, leptin and adiponectin concentration in ATAGA, ATSGA, ATLGA, PTAGA and PTSGA subgroups newborn's serum.

\begin{tabular}{|c|c|c|c|c|c|c|}
\hline & \multicolumn{3}{|c|}{ Term (AT) } & \multicolumn{2}{|c|}{ Preterm (PT) } \\
\hline & & AT-AGA & AT-LGA & AT-SGA & PT-AGA & PT-SGA \\
\hline \multirow[t]{3}{*}{$\overline{B W}(\mathrm{~kg})$} & & $3.4 \pm 0.2^{a, b}$ & $4.5 \pm 0.4^{a b}$ & $2.4 \pm 0.3^{a, b}$ & $1.9 \pm 0.3^{a}$ & $1.4 \pm 0.2^{b}$ \\
\hline & M & $3.5 \pm 0.3$ & $4.2 \pm 0.1$ & $2.5 \pm 0.2$ & $1.9 \pm 0.3$ & $1.4 \pm 0.2$ \\
\hline & $\mathrm{F}$ & $3.5 \pm 0.2$ & $4.6 \pm 0.5$ & $2.4 \pm 0.3$ & $1.9 \pm 0.3$ & $1.4 \pm 0.2$ \\
\hline \multirow[t]{3}{*}{$\mathrm{BL}(\mathrm{cm})$} & & $50.6 \pm 2.2^{\mathrm{a}}$ & $52.5 \pm 3.7^{\mathrm{a}}$ & $47.1 \pm 2.2^{\mathrm{a}}$ & $43.9 \pm 2.6^{a}$ & $40.6 \pm 2.3^{a}$ \\
\hline & M & $50.5 \pm 2.9$ & $52.4 \pm 1.0$ & $47.4 \pm 1.7$ & $43.9 \pm 2.5$ & $40.4 \pm 2.5$ \\
\hline & $\mathrm{F}$ & $50.9 \pm 0.9$ & $52.7 \pm 4.8$ & $46.6 \pm 2.8$ & $44.0 \pm 2.8$ & $40.8 \pm 2.4$ \\
\hline \multirow{3}{*}{$\begin{array}{l}\mathrm{BW} / \mathrm{BL} \\
(\mathrm{gr} / \mathrm{cm})\end{array}$} & & $68.9 \pm 5.7^{\mathrm{a}}$ & $85.7 \pm 10.1^{a}$ & $51.9 \pm 4.6^{a}$ & $44.1 \pm 5.5^{\mathrm{a}}$ & $34.8 \pm 4.5^{\mathrm{a}}$ \\
\hline & M & $68.7 \pm 6.9$ & $88.9 \pm 12.1$ & $53.0 \pm 3.3$ & $43.3 \pm 5.4$ & $35.5 \pm 5.7$ \\
\hline & $\mathrm{F}$ & $69.0 \pm 4.1$ & $81.1 \pm 2.5$ & $50.5 \pm 5.7$ & $44.9 \pm 5.7$ & $33.8 \pm 2.1$ \\
\hline \multirow[t]{3}{*}{ PI (Rohrer) } & & $2.7 \pm 0.5^{\mathrm{a}, \mathrm{b}}$ & $3.2 \pm 1.0^{\mathrm{a}, \mathrm{b}, \mathrm{c}}$ & $2.3 \pm 0.2^{\circ}$ & $2.3 \pm 0.2^{\mathrm{a}}$ & $2.1 \pm 0.3^{b}$ \\
\hline & M & $2.7 \pm 0.7$ & $3.0 \pm 0.2$ & $2.4 \pm 0.1$ & $2.3 \pm 0.3$ & $2.2 \pm 0.2$ \\
\hline & $\mathrm{F}$ & $2.7 \pm 0.2$ & $3.4 \pm 1.3$ & $2.3 \pm 0.3$ & $2.2 \pm 0.1$ & $2.0 \pm 0.3$ \\
\hline & & $13.6 \pm 1.7^{\mathrm{a}, \mathrm{b}}$ & $16.5 \pm 3.3^{\mathrm{a}, \mathrm{b}}$ & $11.0 \pm 0.8^{\mathrm{b}}$ & $10.0 \pm 0.9^{\mathrm{a}}$ & $8.6 \pm 1.0^{\mathrm{b}}$ \\
\hline \multirow[t]{2}{*}{$\left(\mathrm{kg} / \mathrm{m}^{2}\right)$} & $\mathrm{M}$ & $13.7 \pm 2.3$ & $15.5 \pm 0.6$ & $11.2 \pm 0.5$ & $9.8 \pm 1.1$ & $8.7 \pm 1.1$ \\
\hline & $\mathrm{F}$ & $13.6 \pm 0.8$ & $17.7 \pm 4.1$ & $10.8 \pm 1.1$ & $10.2 \pm 0.8$ & $8.3 \pm .0 .9$ \\
\hline Leptin & & $1.9 \pm 0.7^{\mathrm{a}, \mathrm{b}}$ & $3.1 \pm 1.3^{\mathrm{a}, \mathrm{b}, \mathrm{c}}$ & $1.7 \pm 0.5^{c}$ & $1.3 \pm 0.4^{\mathrm{a}}$ & $1.1 \pm 0.3^{\mathrm{b}, \mathrm{c}}$ \\
\hline concentratio & M & $2.0 \pm 0.8$ & $2.8 \pm 1.1$ & $1.8 \pm 0.5$ & $1.2 \pm 0.3$ & $1.1 \pm 0.3$ \\
\hline n (ng/mL) & $\mathrm{F}$ & $1.8 \pm 0.6$ & $3.3 \pm 1.4$ & $1.6 \pm 0.6$ & $1.4 \pm 0.4$ & $1.1 \pm 0.3$ \\
\hline \multirow{4}{*}{$\begin{array}{l}\text { Adiponectin } \\
\text { concentratio } \\
\mathrm{n}(\mathrm{ng} / \mathrm{mL})\end{array}$} & & $32.8 \pm 25.4^{\mathrm{a}, \mathrm{b}}$ & $43.4 \pm 16.9^{\mathrm{a}, \mathrm{b}}$ & & & \\
\hline & & & & $12.7 \pm 2.4^{c}$ & $10.5 \pm 5.5^{\mathrm{a}}$ & $7.4 \pm 2.1^{b}$ \\
\hline & M & $30.2 \pm 23.6$ & $41.7 \pm 18.3$ & $13.5 \pm 2.0$ & $8.5 \pm 4.1$ & $6.8 \pm 2.7$ \\
\hline & $\mathrm{F}$ & $35.7 \pm 27.7$ & $44.5 \pm 16.8$ & $11.6 \pm 2.7$ & $12.5 \pm 6.1$ & $8.2 \pm 0.6$ \\
\hline
\end{tabular}


$(p<0.01 ; p<0.01)$. There was a significant difference between leptin levels $(1.93 \pm 0.70 ; 1.71 \pm 0.53$ vs $3.12 \pm$ $1.27 \mathrm{ng} / \mathrm{mL}$ ) in AT-AGA and AT-SGA compared to ATLGA newborns, $(p<0.01 ; p<0.01)$.

Since neither leptin, nor adiponectin levels were significantly different in male compared to female newborns, no additional gender adjustment was performed during the analysis. This is inline with the thesis that other factors influence leptin and adiponectin serum concentration in this starting growth period of the newborn.

The levels of leptin and adiponectin were strongly correlated with all anthropometric variables $(p<0.001)$ as can be seen in Table 3.

Table 3: Correlations between anthropometric data, leptin and adiponectin concentrations.

\begin{tabular}{cccccc}
\hline & BMI & PI & BW & BW/BL & BL \\
\hline Leptin & $r=0.572$ & $r=0.377$ & $r=0.670$ & $r=0.654$ & $r=0.558$ \\
Adiponectin & $r=0.601$ & $r=0.380$ & $r=0.717$ & $r=0.697$ & $r=0.584$ \\
\hline All correlation cofficients
\end{tabular}

Multiply regression analyses showed significant influence of BW on leptin $\left(b_{B W}=0.696\right)$ and adiponectin $\left(b_{B W}=0.827\right)$ levels and non significant influence of GA (leptinb $_{\mathrm{GA}}=-0.030$; adiponectinb $_{\mathrm{GA}}=0.140$ ), even that in both cases model explains only about $50 \%$ of the variance $\left(R_{\text {leptin }}^{2}=0.4491 ; R_{\text {adiponectin }}^{2}=0.5214\right)$.

\section{Discussion}

Development of adipose tissue in fetal life depends on genetic factors and fetal nutrition. Its amount highly depends on gestational age since adipocytes develop (in number and volume) mainly in the last trimester of pregnancy. Gestational age is crucial for development of adipose tissue and, therefore influences a lot in adipokine secretion and other consecutive metabolic and endocrine factors. Adaptation of extrauterine life, among other factors, depends on the amount of adipose tissue. Conversely, adipose tissue peptides have important role in weight and metabolic control afterwards in life. A process termed "programming", first described by Lucas, is thought to be responsible in reaching this control. Several studies pointed out that nutritional status in fetuses and newborns, as well as diet regimen in the first months has a great impact on metabolic status in the whole life of an individual $[32,33]$. Prolonged breast feeding seems to be associated with decreased risk of obesity and metabolic related diseases in later life than formula feeding. Human milk contains various hormones and growth factors involved in energy metabolism. Recent studies observe that the different hormonal values together with different protein intake could account for growth differences between breast fed and formula fed infants during the period of infancy and in later life [34-39]. Brest fed infants have higher serum leptin levels that correlate positively with maternal BMI [40]. Since diet regiment is difficult to estimate and early in life, preterm infants correlated with those born on term are "natural experiment" of special interest in assessing markers that can be followed up. A number of articles in the literature (referred in further text) point out that such marker are adipokines.

In our study three groups of neonates (AGA, LGA, SGA) born on time (AT) or preterm (PT) were analyzed. In the whole investigated group of neonates, there was a positive correlation between birth weight, $\mathrm{BMI}$ and $\mathrm{PI}$ and concentration of leptin and adiponectin. This is in concordance with other studies and occurs as a result of exponential elevation of leptin production from the growing adipose tissue during the last trimester of pregnancy $[22,29]$. Some studies showed declining in leptin values within the first days after birth, probably due to the reduction of the amount of the adipose tissue and difference in nutritional pattern (placental-oral) during this period $[30,41]$. There were no sex differences in leptin concentrations in our studies, which is concordant with findings in the cohort described by Schubring and Trifiro. The opposite findings is described in the study of Jaquet, where females had higher leptin levels [29, 42]. Other body parameters, such as head and chest circumference do not show correlation with adipokine levels, unlike in the study of Lakho, where positive correlations between $\mathrm{HC}$ and leptin levels were found [43].

The relationship between maternal and fetal metabolism is complex. The mechanism of increasing both maternal and fetal body fat, especially during the last several months of pregnancy depends on hormonal, genetic and environmental changes and is still poorly understood [29]. Since adipokines contribute to a fat metabolism, some studies point out the association between leptin levels and maternal weight gain. Our study didn't show any correlation between leptin levels in newborn and BMI in mothers, as shown in the study of Papadopulou [44]. Geary stated positive correlation between maternal leptin levels and maternal obesity, and separately, positive correlation between neonatal leptin concentrations and neonatal BW [45]. Relationship 
between maternal-neonatal data was not found, suggesting that there are two different compartments with different underlying mechanisms.

In the group of neonates born on time a significantly elevated leptin concentration was found in neonates with higher BW. This correlation was found in other studies that confirms the positive correlation between BW and leptin levels [29, 43, 45, 46]. The levels of adiponectin in LGA and AGA neonates were significantly higher than the values in SGA, as found in other studies [47, 48]. However, low adiponectin level in SGA newborns in that age does not suggest intrauterine insulin resistance, but could be a causative factor for insulin resistance later in life.

In the preterm infants there was no difference in leptin levels in PT-AGA and PT-SGA newborns. Leptin level was similar to that in term -SGA neonates, which is concordant with amount of adipose tissue, rather than gestational age. This findings correlate with studies of Ertl and $\mathrm{Ng}[49,50]$. Ng pointed out constant elevation of leptin levels after day 14 , when weight gain is starting. He also stated that "adipoinsular axis" works early, probably earlier than 34 gestational age [50]. Adiponectin levels are also lower in preterm infants in our study, as well as in the others[20,48]. Recent studies refer leptin, adiponectin and resistin have been found at lower levels in pre-term infants compared to term newborns, unlike ghrelin levels [51]. Adiponectin level in SGA and preterm infants, may represent a marker for development of obesity and metabolic syndrome during adulthood. The severity of SGA in newborns correlates with lower adiponectin levels and obesity later in life.

Conclusion: Adipokines are a reliable marker in establishing metabolic control. This study confirms that these adipocytokines depend on gestational age and ponderal index. Significantly higher adiponectin levels were found in AGA neonates compared to lower values in SGA neonates, and leptin levels are elevated only in macrosomic babies. Leptin and adiponectine levels are more likely to correlate with birth weight than with gestational age.

\section{References}

1. Singhal A, Lucas A. Early origins of cardiovascular disease: is there a unifying hypothesis? Lancet. 2004;363:1642-5.

2. Hofman PL, Regan F, Jackson WE, et al. Premature birth and later insulin resistance. N Engl J Med. 2004;351:217986.
3. Leipala JA, Raivio KO, Sarnesto A, Panteleon A \& Fellman $\checkmark$. Intrauterine growth restriction and postnatal steroid treatment effects on insulin sensitivity in preterm neonates. J Pediatrics. 2002;141:472-476.

4. Rotteveel J, vanWeissenbruch MM, Twisk JW \& DelemarreVan de Waal HA. Infant and childhood growth patterns, insulin sensitivity, and blood pressure in prematurely born young adults. Pediatrics. 2008;122:313-321.

5. Campfield LA, Smith FJ Campfield LA, Smith FJ, Guisez Y, Devos R, Burn P. Recombinant mouse OB protein: evidence for a peripheral signal linking adiposity and central neural network. Science. 1995;269:546-9.

6. Salbe AD, Nicolson M, Ravussin E. Total energy expenditure and the level of physical activity correlate with plasma leptin concentrations in five-year-old children. J Clin Invest. 1997;99:592-5.

7. Auwerx J, Staels B. Leptin. Lancet. 1998;351(9104):73742.

8. Cohen B, Novick D, Rubinstein M. Modulation of insulin activities by leptin. Science. 1996;274:1185-8.

9. Glasow A, Haidan U, Hilbers $M$, et al. Expression of ob receptor in normal human adrenals: differential regulation of adrenocortical and adrenomedullary function by leptin. J Clin Endocrinol Metab. 1998;83:4459-66.

10. Marchini G, Fried G, Östlund E, Hagenäs L. Plasma leptin in infants: relations to birth weight and weight loss. Pediatrics. 1998;101:429-32.

11. Alves SE, Akbari HM, Anderson GM, Azmitia EC, McEwen BC, Strand FL. Neonatal ACTH administration elicits long-term changes in forebrain monoamine innervation. Subsequent disruptions in hypothalamic-pituitary-adrenal and gonadal function. Ann N Y Acad Sci. 1997;814:226-51.

12. Hales CN, Barker DJ, Clark PM, Cox LJ, Fall C, Osmond $C$, Winter PD. Fetal and infant growth and impaired glucose tolerance at age 64. BMJ. 1991;303(6809):1019-22.

13. Smythe JW, McCormick CM, Meaney MJ. Median eminence corticotrophin-releasing hormone content following prenatal stress and neonatal handling. Brain Res Bull. 1996;40(3):195-9.

14. Nedvidkova J, Smitka K, Kopsky V, et al. Adiponectin, an adipocyte-derived protein. Physiol Res. 2005;54:133-40.

15. Meier $U$ \& Gressner AM. Endocrine regulation of energy metabolism: review of pathobiochemical and clinical chemical aspects of leptin, ghrelin, adiponectin, and resistin. Clinical Chemistry. 2004;50:1511-1525.

16. Matsubara M, Maruoka S, Katayose S. Inverse relationship between plasma adiponectin and leptin concentrations in normal-weight and obese women. Eur J Endocrinol. 2002;147:173-80. 
17. Stefan N, Bunt JC, Salbe AD, et al. Plasma adiponectin concentrations in children: Relationships with obesity and insulinemia. J Clin Endocrinol Metab. 2002;87:4652-6.

18. Chan TF, Yuan SS, Chen HS, et al. Correlations between umbilical and maternal serum adiponectin levels and neonatal birthweights. Acta Obstet Gynecol Scand. 2004;83:165-9.

19. Lindsay RS, Walker JD, Havel PJ, et al. Adiponectin is present in cord blood but is unrelated to birth weight. Diabetes Care. 2003;26:2244-9.

20. Siahanidou T, Mandyla $H$, et al. Circulating levels of adiponectin in preterm infants. Arch Dis Child Fetal Neonatal. 2007; 92:f286-290.

21. Guerre-Millo M. Adipose tissue and adipokines: for better or worse. Diabetes Metab. 2004;30(1):13-9.

22. Jaquet D, Leger J, Levy-Marchal C, Oury JF, Czernichow $P$. Ontogeny of leptin in human fetuses and newborn: Impact of intrauterine growth retardation on serum leptin concentrations. J Clin Endocrinol Metab. 1998;83:1243-1246.

23. Kieffer TJ, Heller RS, Habener JF. Leptin receptors expressed on pancreatic â cells. Biochem Biophys Res Commun. 1996;224:522-7.

24. Gaillard RC, Spinedi E, Chautard T, Pralong FP. Cytokines, leptin, and the hypothalamo-pituitary-adrenal axis. Ann N Y Acad Sci. 2000;917:647-57.

25. Mantzoros CS, Ozata M, Negrao AB, Suchard MA, Ziotopoulou M, Caglayan S, Elashoff RM, Cogswell RJ, Negro P, Liberty V, Wong ML, Veldhuis J, Ozdemir IC, Gold PW, Flier JS, Licinio J. Synchronicity of frequently sampled thyrotropin (TSH) and leptin concentrations in healthy adults and leptindeficient subjects: evidence for possible partial TSH regulation by leptin in humans. J Clin Endocrinol Metab. 2001;86(7):328491.

26. Djiane J, Attig L. Role of leptin during perinatal metabolic programming and obesity. J Physiol Pharmacol. 2008;59 Suppl 1:55-63.

27. Sivan E, Lin WM, Homko CJ, Reece EA, Boden G. Leptin is present in human cord blood. Diabetes. 1997;46(5):917-9.

28. Tsai PJ, Yu CH, Hsu SP, Lee YH, Chiou CH, Hsu YW, Ho $\mathrm{SC}, \mathrm{Chu} \mathrm{CH}$. Cord plasma concentrations of adiponectin and leptin in healthy term neonates: positive correlation with birthweight and neonatal adiposity. Clin Endocrinol (Oxf). 2004;61(1):88-93.

29. Schubring C, Siebler T, Kratzsch J, Englaro P, Blum WF, Triep K, Kiess W. Leptin serum concentrations in healthy neonates within the first week of life: relation to insulin and growth hormone levels, skinfold thickness, body mass index and weight. Clin Endocrinol (Oxf). 1999;51(2):199-204.

30. Harigaya A, Nagashima K, Nako Y, Morikawa A. Relationship between concentration of serum leptin and fetal growth. J Clin Endocrinol Metab. 1997;82(10):3281-4.

31. Tsai PJ, Yu CH, Hsu SP, Lee YH, Chiou CH, Hsu YW, Ho $\mathrm{SC}$, Chu $\mathrm{CH}$. Cord plasma concentrations of adiponectin and leptin in healthy term neonates: positive correlation with birthweight and neonatal adiposity. Clin Endocrinol (Oxf). 2004;61(1):88-93.

32. Lucas A. Programming by early nutrition in man. Ciba Found Symp. 1991;156:38-50; discussion 50-5.

33. Morley R, Lucas A. Randomized diet in the neonatal period and growth performance until 7.5-8 y of age in preterm children. Am J Clin Nutr. 2000;71(3):822-8.

34. Savino F, Liguori SA, Petrucci E, Lupica MM, Fissore MF, Oggero R, Silvestro L. Evaluation of leptin in breast milk, lactating mothers and their infants. Eur J Clin Nutr. 2010;64 (9):972-7;

35. Savino F, Liguori SA, Fissore MF, Palumeri E, Calabrese R, Oggero R, Silvestro L, Miniero R. Looking for a relation between serum leptin concentration and body composition parameters in healthy term infants in the first 6 months of life. J Pediatr Gastroenterol Nutr. 2008;46(3):348-51;

36. Savino F, Fissore MF, Liguori SA, Oggero R. Can hormones contained in mothers' milk account for the beneficial effect of breast-feeding on obesity in children? Clin Endocrinol (Oxf). 2009;71(6):757-65;

37. Savino F, Petrucci E, Nanni G. Adiponectin: an intriguing hormone for paediatricians. Acta Paediatr. 2008;97(6):701-5;

38. Savino F, Liguori SA. Update on breast milk hormones: leptin, ghrelin and adiponectin. Clin Nutr. 2008;27(1):42-7.

39. Savino F, Sorrenti M, Benetti S, Lupica MM, Liguori SA, Oggero R. Resistin and leptin in breast milk and infants in early life. Early Hum Dev. 2012;88(10):779-82;

40. Savino F, Liguori SA, Fissore MF, Palumeri E, Oggero R, Silvestro L, Miniero R. Maternal BMI and serum leptin concentration of insulin in the first year of life. Acta Paediatr. 2006;95(4):414-8

41. Matsuda J, Yokota I, lida M, Murakami T, Yamada M, Saijo T, Naito E, Ito M, Shima K, Kuroda Y. Dynamic changes in serum leptin concentrations during the fetal and neonatal periods. Pediatr Res. 1999;45(1):71-5.

42. Trifiro G, Bevilacqua M, Vago T, Baldi G, Motta G, Norbiato G. No gender effect of leptin levels in newborn but significant relationship between leptin and body mass index. Horm Res. 1997;48(Suppl 2):32.

43. Lakho GR, Haq Z, Chundrigar T, Nazir K, Qureshi MA. Cord blood leptin levels in Pakistani newborns: relationship with birth weight, length and occipitofrontal circumference. J Coll Physicians Surg Pak. 2006;16(6):393-5.

44. Papadopoulou FG, Mamopoulos AM, Triantos A, 
Constantinidis TC, Papadimas J, Assimakopoulos EA, Koliakos G, Mamopoulos M. Leptin levels in maternal and cord serum: relationship with fetal development and placental weight. J Matern Fetal Med. 2000;9(5):298-302.

45. Geary M, Pringle PJ, Persaud M, Wilshin J, Hindmarsh PC, Rodeck CH, Brook CG. Leptin concentrations in maternal serum and cord blood: relationship to maternal anthropometry and fetal growth. Br J Obstet Gynaecol. 1999;106(10):105460.

46. Wiznitzer A, Furman B, Zuili I, Shany S, Reece EA, Mazor M. Cord leptin level and fetal macrosomia. Obstet Gynecol. 2000;96(5 Pt 1):707-13.

47. Wolf $\mathrm{HJ}$, Ebenbichler $\mathrm{CF}$, Huter O, Bodner J, Lechleitner M, Föger B, Patsch JR, Desoye G. Fetal leptin and insulin levels only correlate inlarge-for-gestational age infants. Eur J Endocrinol. 2000;142(6):623-9.
48. Saito M, Nishimura K, Nozue H, Miyazono Y, Kamoda T. Changes in serum adiponectin levels from birth to termequivalent age are associated with postnatal weight gain in preterm infants. Neonatology. 2011;100(1):93-8.

49. Ertl T, Funke S, Sárkány I, Szabó I, Rascher W, Blum WF, Sulyok E. Postnatal changes of leptin levels in full-term and preterm neonates: their relation to intrauterine growth, gender and testosterone. Biol Neonate. 1999;75(3):167-76.

50. Ng PC, Lam CW, Lee CH, Wong GW, Fok TF, Wong E, Chan IH, Ma KC. Changes of leptin and metabolic hormones in preterm infants: a longitudinal study in early postnatal life. Clin Endocrinol (Oxf). 2001;54(5):673-80.

51. Savino F, Liguori SA, Lupica MM. 2010. Adipokines in breast milk and preterm infants. Early Hum Dev. 2010;86(Suppl 1):77-80. 